\title{
Impact of Dosing Intervals on Activity of Gentamicin and Ticarcillin Against Pseudomonas aeruginosa in Granulocytopenic Mice
}

\author{
A. U. Gerber, W. A. Craig, H.-P. Brugger, \\ C. Feller, A. P. Vastola, and J. Brandel
}

\author{
From the Department of Medicine, Willam S. Middleton \\ Memorial V.A. Hospital and University of Wisconsin, \\ Madison, Wisconsin; and the Department of Medicine and \\ Institute of Medical Microbiology, University of Bern, \\ Bern, Switzerland
}

\begin{abstract}
The influence of dosing intervals on the activity of gentamicin and ticarcillin against Pseudomonas aeruginosa was studied in vivo. Granulocytopenic mice infected with $P$. aeruginosa in the thigh muscle were treated with 1-hr or 3-hr injections of gentamicin, ticarcillin, or gentamicin-ticarcillin. Plasma pharmacokinetics of the drugs were correlated with antibacterial activity. Gentamicin injected every $1 \mathrm{hr}$ tended to be less active than gentamicin injected at longer intervals. In contrast, ticarcillin given every $1 \mathrm{hr}$ was significantly more efficacious than equivalent total doses injected every $3 \mathrm{hr}$. The dosing schedule of gentamicin-ticarcillin was again important for ticarcillin but did not appreciably affect the antibacterial activity of gentamicin. Thus, antimicrobial chemotherapy of $P$. aeruginosa infections in the granulocytopenic host might be improved by administering ticarcillin rather than gentamicin as a constant infusion.
\end{abstract}

The optimal antibiotic treatment of gram-negative bacterial infections in granulocytopenic patients remains an unsolved clinical problem, particularly for infections due to Pseudomonas aeruginosa, although progress has been made by combining antipseudomonal drugs and by using doses approaching toxic levels. Additional progress could possibly be made by finding optimal dosing schedules for these drugs. This aspect of antimicrobial chemotherapy has hardly been investigated. In some recent clinical trials aminoglycoside antibiotics were administered as constant infusions [1-3]. Although it was concluded that such infusions might be more effective than intermittent dosing, the results supporting this conclusion were not significant. In vitro, no superiority could be demonstrated for constant infusions vs. intermittent doses of gentamicin against $P$. aeru-

Received for publication September 7, 1982, and in revised form December 28, 1982.

Parts of this study were presented at the 54th Annual Meeting of the Central Society for Clinical Research, held in Chicago, Illinois, on November 5-7, 1981, and at the Second International Symposium of Infections in the Immunocompromised Host, held in Stirling, Scotland, on June 20-24, 1982.

This work was supported by funds from the Swiss and Bernese League Against Cancer, the Veterans Administration, Beecham AG, and Essex AG.

Please address requests for reprints to Dr. A. U. Gerber at his present address: University Clinic of Internal Medicine, Inselspital, 3010 Bern, Switzerland. ginosa [4]. An early experimental approach to the importance of dosing schedules in an experimental model in vivo [5] has never been further explored nor has it been expanded to the immunocompromised host.

In the present study an attempt was made to elucidate the impact of dosing intervals on the activity of gentamicin and ticarcillin against $P$. aeruginosa in granulocytopenic mice. For each drug alone and in combination the antibacterial effect of identical total amounts of drug given by two different dosing schedules was quantitated and compared: a 3-hr schedule, which during dosage intervals allowed plasma drug levels to fall below the MIC for the target organism, and a 1 -hr regimen, which did not.

\section{Materials and Methods}

Organisms. $\quad P$. aeruginosa strain ATCC 27853 (American Type Culture Collection, Rockville, Md.) was the main study organism. A previously well-studied clinical isolate $(14974)[4,6,7]$ and two recent clinical isolates (A 10 and E 29/2), all from the Institute of Medical Microbiology (Bern, Switzerland), were included in confirmatory experiments. All organisms studied were susceptible to gentamicin and ticarcillin by the method of Bauer et al. [8]. MICs and MBCs for the main study organism as determined with various methods and media are shown in table 1. 
Table 1. MICs $(\mu \mathrm{g} / \mathrm{ml})$ and MBCs $(\mu \mathrm{g} / \mathrm{ml})$ of gentamicin and ticarcillin for Pseudomonas aeruginosa strain ATCC 27853, as determined using various techniques, media, and bacterial inocula.

\begin{tabular}{|c|c|c|c|c|}
\hline \multirow[b]{2}{*}{ Drug } & \multirow[b]{2}{*}{ Method } & \multirow[b]{2}{*}{ Medium* } & \multicolumn{2}{|c|}{ Inoculum ${ }^{\dagger}$} \\
\hline & & & $\sim 5 \times 10^{5} \mathrm{cfu} / \mathrm{ml} l^{\ddagger}$ & $\sim 10^{7} \mathrm{cfu} / \mathrm{ml}^{\S}$ \\
\hline \multirow[t]{3}{*}{ Gentamicin } & Agar dilution & MHA & $2(-)$ & $2(-)$ \\
\hline & Macrodilution & MHB & $0.25(0.5)$ & $0.5(1)$ \\
\hline & & SMHB & $2(4)$ & $4(8)$ \\
\hline Ticarcillin & Macrodilution & MHB & $32(32)$ & $64(>256)$ \\
\hline
\end{tabular}

* MHA = Mueller-Hinton agar; MHB = Mueller-Hinton broth; SMHB = MHB supplemented with $50 \mathrm{mg}$ of $\mathrm{Ca}^{++}$and $20 \mathrm{mg}$ of $\mathrm{Mg}^{++} /$liter. Corresponding media were used to dilute the drug as well as the inoculum.

$\dagger$ MIC (MBC, defined as $\geqslant 3-\log$ reduction of cfu by $24 \mathrm{hr}$ ).

$\ddagger$ By agar dilution method $5 \times 10^{3} \mathrm{cfu}$ per spot.

$\$$ By agar dilution method $5 \times 10^{5}$ cfu per spot.

Media. Mueller-Hinton broth and MuellerHinton agar (BBL Microbiology Systems, Cockeysville, Md.) used for preliminary in vitro studies were supplemented with $\mathrm{Ca}^{++}$and $\mathrm{Mg}^{++}$according to the procedure of Stratton and Reller [9]. MICs and MBCs were determined in Mueller-Hinton broth and supplemented Mueller-Hinton broth according to standard methods [10].

Drugs. Gentamicin and ticarcillin used for in vitro MIC determinations were powders obtained from Schering Corp. (Kenilworth, N.J.) and Beecham Laboratories (Bristol, Tenn.), respectively. Drugs used for in vivo studies were commercial products: cyclophosphamide (Mead Johnson Pharmaceuticals, Evansville, Ind.), gentamicin (Schering), and ticarcillin (Beecham).

Mice. Female ICR mice weighing 26-30 g each were obtained from Harlan Sprague Dawley (Madison, Wis.) and Tierzucht der Universität Tierspital (Zurich).

Production and confirmation of granulocytopenia. Granulocytopenia was produced by two ip injections of cyclophosphamide, 150 and $100 \mu \mathrm{g} / \mathrm{g}$ at four days and one day, respectively, before the mice were infected with $P$. aeruginosa. Leukopenia was confirmed in six to 10 animals in each experiment on day 4 or 5 after the first injection of cyclophosphamide. Blood $(20 \mu \mathrm{l})$ was drawn from the retroorbital sinus into Unopettes ${ }^{3}$ capillary pipettes (BBL), and leukocytes were counted with a Coulter counter (Coulter Electronics, Hialeah, Fla.). In addition, blood smears were checked for the presence of granulocytes in some but not all experiments.

Drug kinetics. Concentrations of antibiotics were determined in three to six animals per sam- pling point. With the animal under slight ether anesthesia, blood was drawn from the retroorbital sinus into heparinized micro-hematocrit tubes (Clay Adams, Parsippany, N.Y.). Plasma drug levels were determined in a biologic assay [11] using Bacillus subtilis strain ATCC 6633 (Difco Laboratories, Detroit) as the indicator organism.

Bacterial inocula and injection of mice. Broth cultures of the study organisms were grown to an OD of 0.3 (measured at $580 \mathrm{~nm}$ ), washed in icecold $0.9 \% \mathrm{NaCl}$, and adjusted to an OD of 0.3 in $0.9 \% \mathrm{NaCl}$. Of this suspension, $0.1 \mathrm{ml}$ (corresponding to $\sim 10^{7} \mathrm{cfu}$ ) was injected into the thigh of a slightly ether-anesthetized granulocytopenic mouse on day 4 of the experiment (that is, four days after the first injection of cyclophosphamide).

Quantitation of bacterial growth and killing. At various intervals after injection of the bacterial inoculum, three mice of each group were killed for study. The infected thigh was removed, immediately homogenized in $4 \mathrm{ml}$ of iced saline $(8.5 \mathrm{~g}$ of $\mathrm{NaCl} /$ liter) supplemented with $50 \mathrm{mg}$ of $\mathrm{Ca}^{++} /$ liter, $20 \mathrm{mg}$ of $\mathrm{Mg}^{++} /$liter, and $0.1 \mathrm{ml}$ of $\beta$-lactamase (Whatman Biochemicals, Maidstone, Kent, England) with a Polytron ${ }^{\circledast}$ tissue homogenizer (Kinematica, Lucerne, Switzerland), and plated in duplicate for cfu determinations.

Treatment of mice. Granulocytopenic mice were allotted to treatment groups, being treated essentially with either a 1-hr or a 3-hr regimen. Experiments were devised such that identical cumulative doses of the study drug(s) resulted by the time the animals were killed for study. Animals were injected sc with $0.2 \mathrm{ml}$ of appropriate dilutions of the drugs. Control mice were injected with 
$0.9 \% \mathrm{NaCl}$. The range of doses studied was 10 $\mu \mathrm{g} / \mathrm{g}$ per $1 \mathrm{hr}$ to $1 \mathrm{mg} / \mathrm{g}$ per $3 \mathrm{hr}$ and $0.833 \mu \mathrm{g} / \mathrm{g}$ per $1 \mathrm{hr}$ to $22.5 \mu \mathrm{g} / \mathrm{g}$ per $3 \mathrm{hr}$ for ticarcillin and gentamicin, respectively. In combination experiments, the two study drugs were injected simultaneously at two different sites.

Evaluation of results and statistics. The direct comparison of results (the effect of identical cumulative doses of drug administered by different schedules) was based on experiments performed with the same bacterial inoculum on the same day injected into randomly selected granulocytopenic mice.

Calculations of the $t^{1 / 2}$ values of gentamicin and ticarcillin were based on the assumption that the drug had been absorbed from the site of injection by $15 \mathrm{~min}$ after the injection. Analysis of regression and analysis of covariance [12] were used to evaluate bacterial growtil curves and dose-response curves for the two study drugs. Wilcoxon's rank sum test for paired samples [12] was used for analyzing results compiled from various and repeated experiments comparing the effect of different dosing schedules.

\section{Results}

Granulocytopenia in mice. Mice were severely granulocytopenic (absolute granulocyte count, $<50 / \mathrm{mm}^{3}$ ) by day 4 and remained so through day 5 after the first injection of cyclophosphamide.
Virtually no granulocytes were found on smears made from blood as well as from Pseudomonasinfected thighs of such mice.

Ticarcillin treatment. The plasma kinetics of ticarcillin were similar in infected and noninfected mice. Plasma levels after sc injection of various doses of ticarcillin are shown in figure 1, left. Assuming complete absorption of the drug by $15 \mathrm{~min}$ after $s c$ injection of $1 \mathrm{mg} / \mathrm{g}$, the $\mathrm{t}^{1 / 2}$ of ticarcillin was $15.6 \mathrm{~min}$.

Figure 2 shows the kinetics of two dosing regimens of ticarcillin as well as the corresponding antipseudomonal effect in the same animals. Granulocytopenic mice were injected in the thigh muscle with $P$. aeruginosa strain ATCC 27853. At $2 \mathrm{hr}$ later, ticarcillin treatment was started with $3 \Omega \mu \mathrm{g} / \mathrm{g}$ every $3 \mathrm{hr}$ in one group and with $10 \mu \mathrm{g} / \mathrm{g}$ every 1 $\mathrm{hr}$ in another group. Peak plasma levels after 30 $\mu \mathrm{g} / \mathrm{g}$ came close to the MIC for the study organisms $(16-32 \mu \mathrm{g} / \mathrm{ml})$ but remained clearly below the $\mathrm{MBC}$, as determined with an inoculum of $10^{7}$ $\mathrm{cfu} / \mathrm{ml}$ in vitro $(>256 \mu \mathrm{g} / \mathrm{ml})$. Doses every $1 \mathrm{hr}$ of $10 \mu \mathrm{g} / \mathrm{g}$ resulted in plasma drug levels that remained below the MIC for the study organisms throughout the experiment. No significant accumulation of ticarcillin was observed. Neither of the two dosing regimens was bactericidal. Yet, bacterial growth was suppressed in animals treated every $1 \mathrm{hr}$ for at least $12 \mathrm{hr}$. In contrast, doses every $3 \mathrm{hr}$ of $30 \mu \mathrm{g} / \mathrm{g}$ were significantly less active, allowing for growth of the study organisms
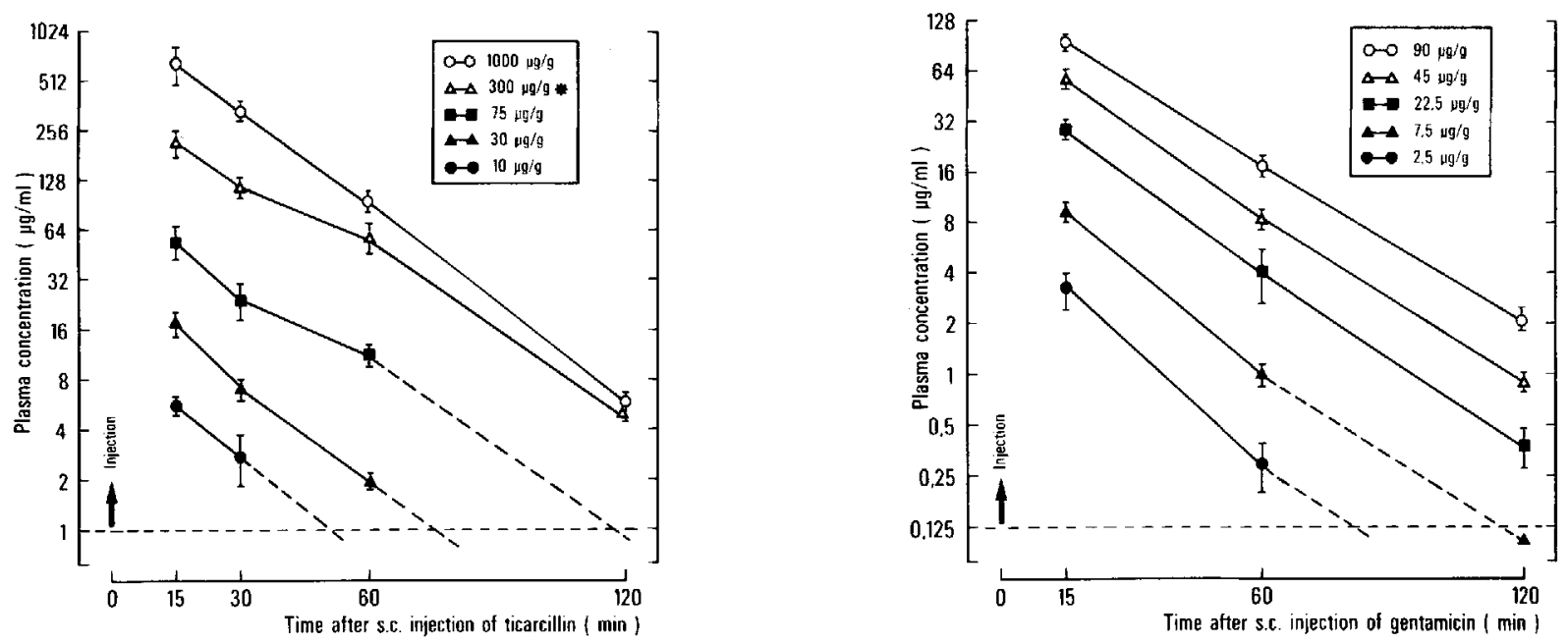

Figure 1. Plasma kinetics of (left) ticarcillin and (right) gentamicin in mice after single sc injections of various doses. Each point represents the mean \pm SD of duplicate determinations from three to (left) six or (right) four mice. Limit of detectability $=(---)$; Pseudomonas aeruginosa strain NCTC 104941 used as indicator organism $=\left({ }^{*}\right)$. 

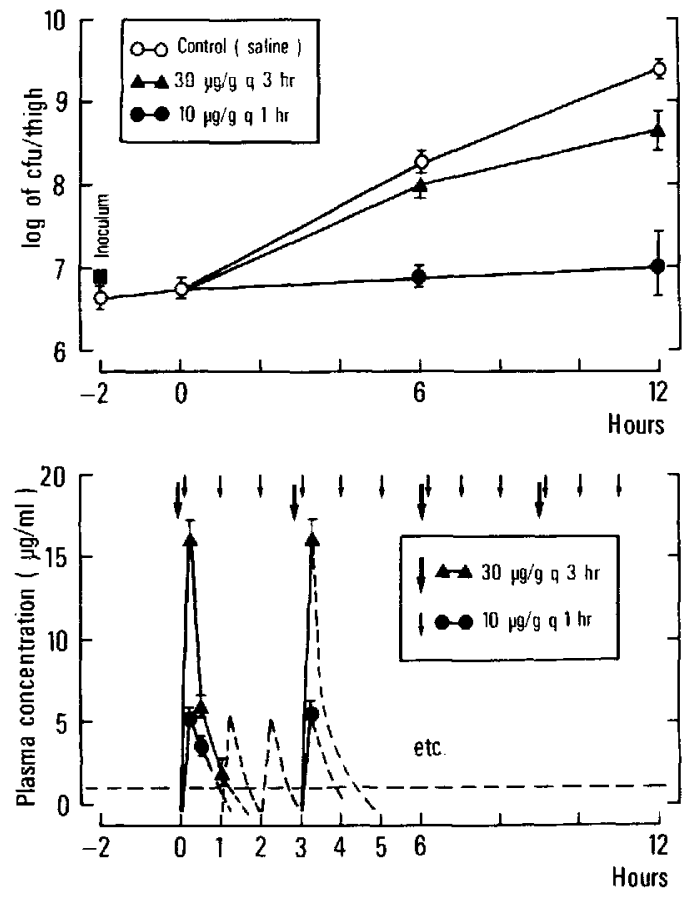

Figure 2. Kinetics of sub-MIC levels of ticarcillin and the corresponding effect on Pseudomonas aeruginosa strain ATCC 27853 in the same granulocytopenic mice. $T o p$, growth kinetics of $P$. aeruginosa in vivo. Each point represents the geometric mean \pm SD number of cfu per thigh in three mice. The differences among the three growth curves are significant $(P<0.01)$. Bottom, plasma kinetics after repeated 3-hr and 1-hr sc injections of ticarcillin (30 and $10 \mu \mathrm{g} / \mathrm{g}$, respectively). Each point stands for the mean \pm SD plasma level in three mice. Limit of detectability $(1 \mu \mathrm{g} / \mathrm{ml})=(---)$.

despite the intermittent higher blood levels of ticarcillin obtained.

Additional experiments in granulocytopenic mice were performed using doses of up to $1 \mathrm{mg}$ of ticarcillin/g. Again, the activity of a 1-hr vs, a 3-hr dosage regimen was studied. The antibacterial effect of ticarcillin proved (I) to be dose related, (2) to depend on the dosage interval, and (3) to fade in prolonged treatment. For both dosing regimens a significant correlation between the log of dose and the pharmacologic response was obtained (figure 3). In addition, a highly significant difference in antipseudomonal efficacy was demonstrated between 1-hr and 3-hr dosing schedules of ticarcillin ( $P<0.01$ by Wilcoxon's rank sum test). A bactericidal threshold dose, defined as the minimal cumulative dose of drug above which a reduction in numbers of living bacteria from infected thighs was observed, was calculated from dose-re- sponse curves ( $x$ for $y=0$ ). At 6 hr of treatment the bactericidal threshold doses of the 1-hr and the 3-hr schedule were 72 and $724 \mu \mathrm{g} / \mathrm{g}$ per $6 \mathrm{hr}$, respectively (with 0.95 confidence limits $21 \leqslant 72$ $\leqslant 199$ and $211 \leqslant 724 \leqslant 2,993 \mu \mathrm{g} / \mathrm{g}$ per $6 \mathrm{hr}$ for $1-\mathrm{hr}$ and 3-hr dosing schedules, respectively). Corresponding bactericidal threshold doses at $12 \mathrm{hr}$ of treatment were $51 \leqslant 207 \leqslant 703$ and $776 \leqslant 1,473$ $\leqslant 2,945 \mu \mathrm{g} / \mathrm{g}$ per $12 \mathrm{hr}$, respectively. Thus, $1-\mathrm{hr}$ injections were estimated to be about seven to 10 times more effective than $3-\mathrm{hr}$ injections yielding identical cumulative doses of ticarcillin. No mode of dosing was more effective after $12 \mathrm{hr}$ of therapy thari after $6 \mathrm{hr}$. Moreover, a trend toward bacterial breakthrough growth was noted even in mice receiving high-dose treatment.

Confirmatory studies included three clinical iso-
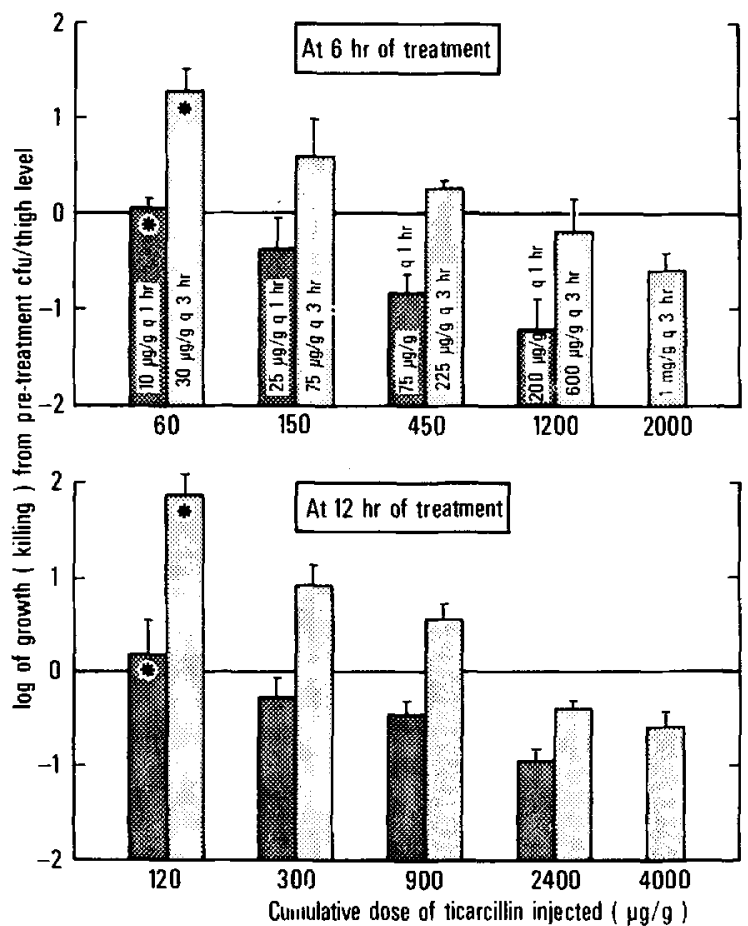

Figure 3. Effect of various cumulative doses of ticarcillin, injected at 1- or 3-hr intervals, in granulocytopenic mice infected with Pseudomonas aeruginosa. Data are geometric mean \pm SD values $(n=3)$ of $\log$ cfu $(t)-$ $\log \mathrm{cfu}\left(t_{0}\right)$, where $t_{0}$ is the time when treatment was started and $t$ is the time after starting the treatment. Values for dose-response curves at $6 \mathrm{hr}$ of treatment (for 1 -hr and 3-hr dosing, respectively) were $r=-0.914$ and -0.886 , intercept $=1.57$ and 2.7 , and slope $=-1.01$ and -1.06 ; at $12 \mathrm{hr}$ of treatment, $r=-0.897$ and -0.965 , intercept $=2.03$ and 5.3 , and slope $=-0.88$ and -1.67 . Data from figure $1=\left(^{*}\right)$. 
lates of $P$. aeruginosa. Two of these strains (strains E 29/2 and A 10) were highly virulent in mice and grew faster than strain ATCC 27853 in vitro and in vivo. They were susceptible to ticarcillin at an MIC of $32 \mu \mathrm{g} / \mathrm{ml}$. In contrast, the third clinical isolate (strain 14974, from a child with cystic fibrosis) grew markedly slower in vitro and in granulocytopenic mice and was susceptible to ticarcillin at an MIC of $2 \mu \mathrm{g} / \mathrm{ml}$. In all confirmatory experiments using these three strains, 1-hr doses of ticarcillin were significantly more efficacious than 3-hr doses. In fact, a 3-hr treatment regimen of ticarcillin using $90 \mu \mathrm{g} / \mathrm{g}$ per $3 \mathrm{hr}$ did not have a bactericidal effect on strain 14974, even though peak drug levels exceeded the $\mathrm{MBC}$ for this organism by at least 32-fold.

Gentamicin treatment. Plasma levels after various doses of gentamicin are shown in figure 1 , right. Assuming complete absorption of the drug by $15 \mathrm{~min}$ after sc injection of $90 \mu \mathrm{g} / \mathrm{g}$, a t $1 / 2$ of 19 min was found. This $t \frac{1}{2}$ tended to be even shorter after injections of lower doses of gentamicin. Accumulation of the drug was occasionally observed in extremely sick mice by $12 \mathrm{hr}$ of treatment. It is interesting that cfu counts per thigh in such mice did not differ from those in mice in which the drug had not accumulated.

Granulocytopenic mice infected with $P$. aeruginosa were comparatively treated with various doses and dosage schedules of gentamicin. Figure 4 depicts results compiled with $P$. aeruginosa strain ATCC 27853. At doses of gentamicin up to $2.5 \mu \mathrm{g} / \mathrm{g}$ per $1 \mathrm{hr}$ and $7.5 \mu \mathrm{g} / \mathrm{g}$ per $3 \mathrm{hr}$, respectively, the efficacy of a 1-hr and a 3-hr dosage schedule was comparable. Both regimens resulted in bacterial breakthrough growth, even when peak plasma levels, at least intermittently, exceeded the MIC for the study organism. Higher doses of gentamicin $(90 \mu \mathrm{g} / \mathrm{g}$ per $12 \mathrm{hr})$ were comparatively studied in four different groups of mice injected every $1 \mathrm{hr}$, every $3 \mathrm{hr}$, every $6 \mathrm{hr}$, or only once per 12-hr period of treatment. A similar partial bactericidal effect was obtained in all four groups of mice at $12 \mathrm{hr}$ of treatment. By this time, the total amount of injected drug was equal in the four dosage regimens studied (that is, cumulative doses of ticarcillin were identical). In contrast, the time course of the bactericidal effect was not the same in the four regimens. The 6-hr and the 12-hr treatment regimens were most efficacious at $3 \mathrm{hr}$ after the first injection of gentamicin (by which time the resulting drug level had fallen below the MIC). Thereafter, regrowth of the surviving organisms occurred. This regrowth was relatively slow when compared with the growth rate of control organisms in saline-treated mice (data not shown). It is interesting that bacterial killing was observed only during the first 3 and $6 \mathrm{hr}$ of treatment, even in those groups of mice that had been injected with gentamicin every $1 \mathrm{hr}$ or $3 \mathrm{hr}$. Later on, no significant additional killing of the study organism occurred, although drug injections were continued.

The antipseudomonal activity of identical cumulative doses of gentamicin at 3 and $6 \mathrm{hr}$ of treatment (figure 4) was compared. A trend toward superiority of 3-hr over 1-hr injections of gentamicin was noted. This trend was corroborated in additional experiments using various inocula of $P$. aeruginosa strain ATCC 27853 and treatment with gentamicin at doses of $5,7.5$, and $15 \mu \mathrm{g} / \mathrm{g}$ per $3 \mathrm{hr}$ (data not shown). A small superiority of 3-hr

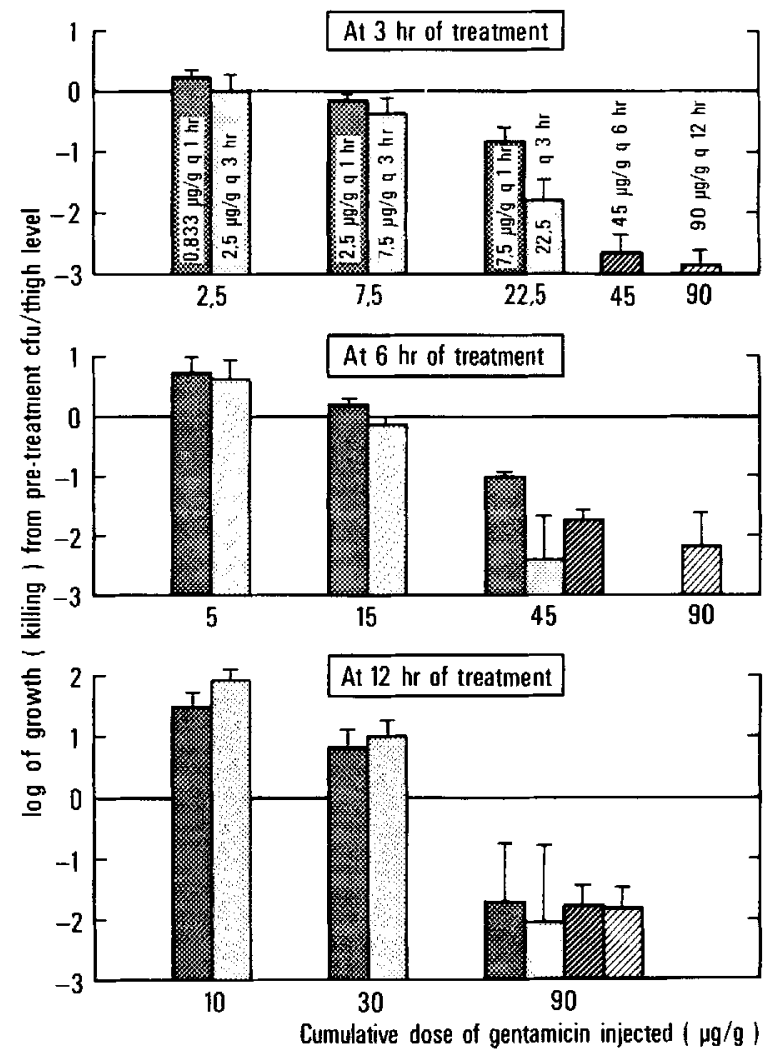

Figure 4. Effect of various cumulative doses of gentamicin, injected at 1-, 3-, 6-, or 12-hr intervals, in granulocytopenic mice infected with Pseudomonas aeruginosa. The MIC of gentamicin for the study organism was $2 \mu \mathrm{g} / \mathrm{ml}$. 
over 1-hr treatment schedules was observed, which proved to be reproducible and consistent when results were compiled from seven experiments $(P$ $<0.01$ by Wilcoxon's rank sum test for paired samples). However, as can be seen from figure 4, this superiority was limited to sampling points at 3 and $6 \mathrm{hr}$ of treatment. By $12 \mathrm{hr}$, when the phenomenon of breakthrough growth became substantial, no such difference could be demonstrated.

All essential results obtained with $P$. aeruginosa strain ATCC 27853 were confirmed in similar experiments using clinical isolates 14974 and E 29/2 as the target organism.

Combined treatment with ticarcillin and gentamicin. In preliminary experiments, in vivo synergy had been demonstrated for the two study drugs in combination. Therefore, relatively low and intermediate doses of the drugs were studied in combination experiments. Dosing regimens using 1and 3-hr intervals were compared.

The four possible combinations were simultaneously investigated. (l) Granulocytopenic mice were treated by the schedule by which each drug had been demonstrated to be least active when given alone, that is, ticarcillin every $3 \mathrm{hr}$ and gentamicin every $1 \mathrm{hr},(2)$ a second group got both drugs every $3 \mathrm{hr}$, and (3) a third group got both drugs every $1 \mathrm{hr}$. (4) A fourth group was treated with ticarcillin every $1 \mathrm{hr}$ plus gentamicin every 3 $\mathrm{hr}$, that is, the schedule by which each drug, when given alone, had proved to be most potent.

The results (figure 5) were as expected. Significantly most effective was the combination of $1-\mathrm{hr}$ injections of ticarcillin with 3-hr injections of gentamicin. Combining 3-hr doses of ticarcillin with 1-hr doses of gentamicin proved to be the least active regimen studied. An analysis of all combination experiments demonstrated the significant $(P$ $<0.01$ ) superiority of 1 -hr vs. 3 -hr regimens of ticarcillin. This superiority did not depend on whether the concomitantly administered gentamicin was injected every $1 \mathrm{hr}$ or every $3 \mathrm{hr}$. In contrast, gentamicin in combination with any ticarcillin schedule studied tended to be more active in 3-hr than in 1 -hr regimens $(P<0.05$ and $P>0.05$ for the lower and higher doses of gentamicin studied, respectively). Breakthrough growth was common predominantly when low doses and less favorable schedules were used. High-dose treatment and optimal dosing intervals were essential

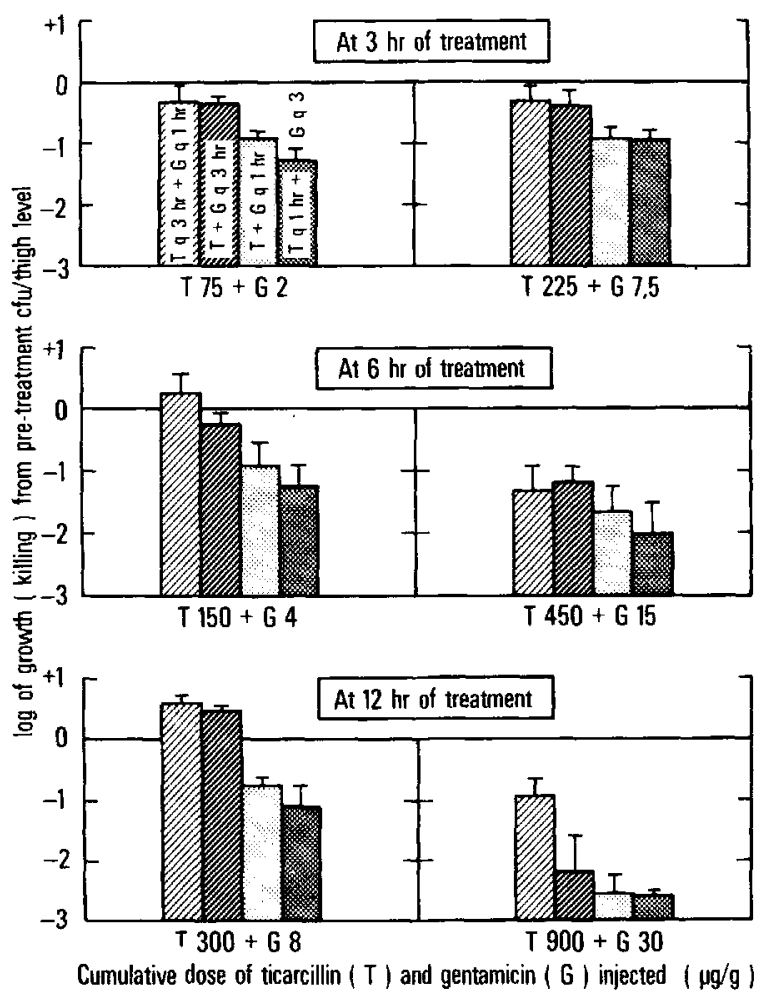

Figure 5. Effect of various cumulative doses of ticarcillin $(T)$ plus gentamicin (G) in granulocytopenic mice infected with Pseudomonas aeruginosa. Left: T $(75 \mu \mathrm{g} / \mathrm{g}$ every $3 \mathrm{hr})+\mathrm{G}(0.67 \mu \mathrm{g} / \mathrm{g}$ every $1 \mathrm{hr}) ; \mathrm{T}(75 \mu \mathrm{g} / \mathrm{g}$ every $3 \mathrm{hr})+\mathrm{G}(2 \mu \mathrm{g} / \mathrm{g}$ every $3 \mathrm{hr}) ; \mathrm{T}(25 \mu \mathrm{g} / \mathrm{g}$ every $1 \mathrm{hr})$ $+\mathrm{G}(0.67 \mu \mathrm{g} / \mathrm{g}$ every $1 \mathrm{hr})$; or $\mathrm{T}(25 \mu \mathrm{g} / \mathrm{g}$ every $1 \mathrm{hr})$ $+\mathrm{G}(2 \mu \mathrm{g} / \mathrm{g}$ every $3 \mathrm{hr})$. Right: Three and 3.75 times higher doses of $\mathrm{T}$ and $\mathrm{G}$, respectively.

for a sustained bactericidal effect of ticarcillin in particular. In confirmatory experiments using two clinical isolates ( $P$. aeruginosa 14974 and E 29/2), the dosing schedule again turned out to be of particular importance for ticarcillin, whereas its impact on the activity of gentamicin was not statistically significant in ticarcillin-gentamicin combinations.

\section{Discussion}

Using an experimental thigh infection model in granulocytopenic mice, we demonstrated the impact of doses and dosing schedules on the time course of the pharmacologic response to two antipseudomonal drugs differing basically in their mechanism of action.

In comparison to humans, unusually high doses of ticarcillin and gentamicin were needed to obtain 
an antibacterial effect in mice. This finding could be explained, at least in part, by the very short $t \frac{1}{2}$ of these drugs in mice. Therefore, our studies included dosing such that peak plasma levels and/or total area-under-the-concentration-vs.-time curves rather than injected amounts of drug were comparable to those seen in patients receiving maximal doses of gentamicin or ticarcillin. Interesting differences in efficacy were found between such dosing of the two drugs. Gentamicin $(2.5 \mu \mathrm{g} / \mathrm{g}$ every $1 \mathrm{hr}$ or $7.5 \mu \mathrm{g} / \mathrm{g}$ every $3 \mathrm{hr}$ ) had only a small and transient effect, whereupon breakthrough growth of the study organisms occurred. This phenomenon has been the subject of previous investigations using the same study organisms $[6,7]$. Ticarcillin, on the other hand, even at relatively low doses $(<75 \mu \mathrm{g} / \mathrm{g}$ every $1 \mathrm{hr}$ ) was significantly more efficacious, with the condition that the interval between drug injections was 1 but not $3 \mathrm{hr}$. When properly spaced, even sub-MIC peak levels of ticarcillin were quite effective, although only bacteriostatic. Thus, in contrast to gentamicin, the effect of ticarcillin was mainly due to the constant presence of the drug, rather than to very high peak levels. These differences in activity between ticarcillin and gentamicin cannot easily be explained by the difference in $t^{1 / 2}$ of the two study drugs. Other factors are likely to be involved.

The presence or absence of a postantibiotic effect could well be of importance in regard to the results of our present study. In vitro exposure of $P$. aeruginosa to gentamicin has been shown to be followed by a period of persistent suppression of bacterial regrowth lasting up to $2 \mathrm{hr}$ after removal of the drug $[4,13]$. In contrast, no postantibiotic effect could be demonstrated with ticarcillin [13]. Thus, in vitro as well as in vivo, $P$. aeruginosa seems to recover immediately as soon as the ticarcillin level has fallen to subactive concentrations, whereas the postantibiotic effect of gentamicin would help to cover the dosing interval of this drug. Yet, this interpretation would not explain our results obtained in experiments combining the two study drugs. In those experiments $1-\mathrm{hr}$ injections of ticarcillin were significantly more active than 3-hr doses, although theoretically the postantibiotic effect of gentamicin should have covered the interval between the 3-hr injections of ticarcillin. This finding clearly demonstrates that additional important factors for optimal administration of antibiotics have to be taken into account.
In this regard, the time lag between drug exposure and onset of bacterial killing might be of paramount importance. After exposure of $P$. aeruginosa to gentamicin, this time lag is short and dependent on drug concentration in vitro as well as in vivo $[4,7]$. In contrast, in the case of penicillins this time lag before the onset of bacterial killing seems to be considerably longer $[14,15]$ (A.U.G. and C.F., unpublished observation). Thus, very short concentration peaks (due to very rapid elimination of the drug) could minimize the in vivo activity of ticarcillin.

It is clear that much additional experimental work is needed, both in vitro and in vivo, to understand how the shape of the concentration-vs.time curve of an antibiotic affects its antimicrobial activity. Moreover, the answer to this question is certainly dependent not only on the antibiotic, its pharmacokinetics, and its mechanism of action, but equally so on the site of infection and the target organism. Our investigations are no more than a first tentative approach to a complex problem. Nevertheless, speculatively extrapolating the results of our findings to the clinical situation, one would postulate that, at least in the presence of leukopenia, ticarcillin rather than an aminoglycoside should be administered as a continuous infusion. It is ironic that this postulate is the exact opposite of what several authors of clinical studies have advocated in recent years [1-3].

\section{References}

1. Feld, R., Valdivieso, M., Bodey, G. P., Rodriguez, V. A comparative trial of sisomicin therapy by intermittent versus continuous infusion. Am. J. Med. Sci. 274:179188, 1977.

2. Feld, R., Tuffnell, P. G., Curtis, J. E., Messner, H. A., Hasselback, R. Empiric therapy for infections in granulocytopenic cancer patients: continuous infusion of amikacin plus cephalothin. Arch. Intern. Med. 139:310 314, 1979.

3. Keating, M. J., Bodey, G. P., Valdivieso, M., Rodriguez, V. A randomized comparative trial of three aminoglycosides-comparison of continuous infusions of gentamicin, amikacin and sisomicin combined with carbenicillin in the treatment of infections in neutropenic patients with malignancies. Medicine (Baltimore) 58:159-170, 1979.

4. Gerber, A. U., Wiprächtiger, P., Stettler-Spichiger, U., Lebek, G. Constant infusions vs. intermittent doses of gentamicin against Pseudomonas aeruginosa in vitro. $\mathbf{J}$. Infect. Dis. 145:554-560, 1982.

5. Hunter, P. A., Rolinson, G. N., Witting, D. A. Effect of 
carbenicillin on pseudomonas infection. In J. D. Williams and A. M. Geddes [ed.]. Chemotherapy. Proceedings of the 9th International Congress of Chemotherapy. Vol. 2. Plenum Press, New York, 1976, p. 289-293.

6. Gerber, A. U., Craig, W. A. Aminoglycoside-selected subpopulations of Pseudomonas aeruginosa: characterization and virulence in normal and leukopenic mice. $J$. Lab. Clin. Med. 100:671-681, 1982.

7. Gerber, A. U., Vastola, A. P., Brandel, J., Craig, W. A. Selection of aminoglycoside-resistant variants of Pseudomonas aeruginosa in an in vivo model. J. Infect. Dis. 146:691-697, 1982.

8. Bauer, A. W., Kirby, W. M. M., Sherris, J. C., Turck, M. Antibiotic susceptibility testing by a standardized single disk method. Am. J. Clin. Pathol. 45:493-496, 1966.

9. Stratton, C. W., Reller, L. B. Serum dilution test for bactericidal activity. I. Selection of a physiologic diluent. J. Infect. Dis. 136:187-195, 1977.

10. Gavan, T. L., Barry, A. L. Microdilution test procedures. In E. H. Lennette, A. Balows, W. J. Hausler, Jr., and J. P. Truant [ed.]. Manual of clinical microbiology. 3rd ed. American Society for Microbiology, Washington, D.C., 1980, p. 459-462.

11. Sabath, L. D., Anhalt, J. P. Assay of antimicrobics. In
E. H. Lennette, A. Balows, W. J. Hausler, Jr., and J. P. Truant [ed.]. Manual of clinical microbiology. 3rd ed. American Society for Microbiology, Washington, D.C., 1980 , p. $485-490$.

12. Snedecor, G. W., Cochran, W. G. Statistical methods. 6th ed. Iowa State University Press, Ames, 1967, p. 128130, 432-438.

13. Bundtzen, R. W., Gerber, A. U., Cohn, D. L., Craig, W. A. Postantibiotic suppression of bacterial growth. Rev. Infect. Dis. 3:28-37, 1981.

14. Gerber, A. U., Bundtzen, R. W., Craig, W. A. Effect of dosing regimens on the activity of antimicrobial agents in an in vivo model. In P. Periti and C. G. Grassi [ed.]. Current chemotherapy and immunotherapy. Proceedings of the 12th International Congress of Chemotherapy. Vol. 1. American Society for Microbiology, Washington, D.C., 1982, p. 124-126.

15. Goto, S. Evaluation of the activity of ticarcillin against experimental Pseudomonas aeruginosa infection in comparison with carbenicillin and sulbenicillin. In $\mathrm{F}$. O'Grady, Y. Ueda, D. Höffler, and H. C. Neu [ed.]. Ticarcillin (BRL 2288). Excerpta Medica, Amsterdam, 1978, p. 3-14. 